\title{
Report of Official Foreign Travel to Canada 2-10 August 2002
}

\author{
James David Mason \\ Internet, SGML, and Integration Services \\ Information Technology Services \\ SAIC
}

26 August 2002

Prepared by the Y-12 National Security Complex

Oak Ridge, Tennessee 37831

managed by

BWXT Y-12, L.L.C.

for the

U.S. DEPARTMENT OF ENERGY

under contract DE-AC05-00OR22800 


\section{DISCLAIMER}

This report was prepared as an account of work sponsored by an agency of the United States Government. Neither the United States Government nor any agency thereof, nor any of their employees, makes any warranty, express or implied, or assumes any legal liability or responsibility for the accuracy, completeness, or usefulness of any information, apparatus, product, or process disclosed, or represents that its use would not infringe privately owned rights. Reference herein to any specific commercial product, process, or service by trade name, trademark, manufacturer, or otherwise, does not necessarily constitute or imply its endorsement, recommendation, or favoring by the United States Government or any agency thereof. The views and opinions of authors expressed herein do not necessarily state or reflect those of the United States Government or any agency thereof. 


\title{
Report of Official Foreign Travel to Canada 2-10 August 2002
}

\author{
James David Mason \\ Internet, SGML, and Integration Services \\ Information Technology Services \\ SAIC
}

26 August 2002

\author{
Prepared by the \\ Y-12 National Security Complex \\ Oak Ridge, Tennessee 37831 \\ managed by \\ BWXT Y-12, L.L.C. \\ for the \\ U.S. DEPARTMENT OF ENERGY \\ under contract DE-AC05-00OR22800
}




\title{
Report of Official Foreign Travel to Canada 2-10 August 2002
}

\author{
James David Mason
}

\begin{abstract}
In support of DOE's use of SGML, XML, HTML, and related standards, I have served since 1985 as Chairman of the international committee responsible for SGML and related standards, ISO/IEC JTC1/SC34 (SC34) and its predecessor organizations. During my August 2002 trip, I attended the summer 2002 meeting of SC34/WG3 in Montréal, Canada. I also read a paper at Extreme Markup Languages 2002, a major conference on the use of SGML and XML sponsored by IDEAlliance.

Supporting standards development allows the Department of Energy/National Nuclear Security Administration (DOE/NNSA) and the Y-12 National Security Complex (Y-12) the opportunity both to provide input into the process and to benefit from contact with some of the leading experts in the subject matter. Oak Ridge has been for some years the location to which other DOE sites turn for expertise in SGML, XML, and related topics.

Note: This report continues a series, the most recent of which, Y/WPP-035, reported on the Spring 2002 meeting of SC34 in Barcelona, Catalonia, Spain. Copies of documentation for all SC34 meetings are available from the SC34 site on the Web: http://www.y12.doe.gov/sgml/sc34/sc34oldhome.htm. This report is available on the SC34 Web site at http://www.y12.doe.gov/sgml/sc34/document/0324.htm. Hyperlinks in the online report connect it to the documents it references.
\end{abstract}

\section{Introduction}

Over the course of the past two decades, SGML (Standard Generalized Markup Language, ISO 8879:1986) and its applications, including HTML (Hypertext Markup Language), and profiles, most notably XML (Extensible Markup Language), have come to dominate the interchange and use of structured data. SGML and many of the standards related to it were developed and are maintained by ISO/IEC JTC1/SC34 (SC34), which I chair.

One of the SC34 projects gaining the most attention recently is Topic Maps (ISO/IEC 13250:2002), which describes metadata structures for organizing and indexing large collections of information resources. The Topic Map standard seems poised to have a major effect on knowledge-management applications. Topic Maps are being used in the knowledge base for the Ferret analytical engine developed at Y-12 and are being investigated as a mechanism for maintaining and publishing classification guidance on a DOEwide basis. Topic Maps also have good potential as a structuring tool in other knowledge-preservation activities.

In August 2002, I attended a series of meetings in Montréal related to the support of SC34 standards and their application. SC34's Working Group 3 (SC34/WG3), Information Association, which is responsible for Topic Maps, met on Saturday, 3 August. The Extreme Markup Languages 2002 conference, sponsored by IDEAlliance, followed during the next week. 


\section{Summer Meeting of ISO/IEC JTC1/SC34/WG3, Montréal, Canada}

The SC34/WG3 meeting on 3-5 August 2001 was attended by 14 experts representing six countries (France, Germany, Japan, Norway, the United Kingdom, and the United States) and two external liaison bodies (International SGML/XML Users' Group, OASIS). I chaired the meeting, in the absence of Steve Pepper, Convenor of WG3.

SC34/WG3 works mainly on matters of hypertext and multimedia documents and linking. The newly revised Topic Maps standard (ISO/IEC 13250, http://www.y12.doe.gov/sgml/sc34/document/0322.htm), which was reissued this year, occupies most of WG3's effort. Since last year, the standard has been revised to include the XML Topic Maps (XTM) interchange data structure developed by TopicMaps.org (now operating under OASIS). At this meeting, WG3 examined two documents related to Topic Map support models, the Standard Application Model, edited by Lars Marius Garshol and Graham Moore (SC34 N329, http://www.y12.doe.gov/sgml/sc34/document/0329.htm), and a Reference Model, edited by Steve Newcomb and Michel Biezunski (SC34 N298, http://www.y12.doe.gov/sgml/sc34/document/0298R1.htm).

The major result of the examination of the models was a series of decisions that are documented in the meeting report. Among the subjects discussed in considerable detail were naming of topics, merging, and the implications of new interpretations for syntax. Probably the most significant decision was a reinterpretation of the "Topic Naming Constraint" to remove some of the undesirable effects of automatic merging that it imposed. Some of these decisions may result in amendments/corrigenda to the Topic Maps standard at a later date.

The Report of the WG3 meeting is available online at http://www.y12.doe.gov/sgml/sc34/document/0331.htm. No new documents were distributed at the meeting.

\section{Conference: Extreme Markup Languages 2002}

IDEAlliance (formerly the Graphic Communications Association, an affiliate of Printing Industries of America) has been a supporter of SGML and its applications from the earliest days. Their conferences on SGML-related topics had already grown steadily over the years, but the arrival of first HTML and then XML has caused an explosion of participation in both North America and Europe. Extreme Markup Languages is IDEAlliance's most technical conference in the area of SGML, XML, and related technologies.

This year's Extreme Markup Languages conference in Montréal revisited several themes from the previous two years, particularly the nature of markup languages, schema languages, and the relationship between RDF and Topic Maps.

This year's discussion of the nature of markup continued with several papers on algebraic approaches to fundamental subjects and on analysis of ways of applying markup to complex subjects. Gavin Nichol's presentation on "Core range algebra" led the algebraic approach and was frequently mentioned by later presenters. Michael Sperberg-McQueen, Allen Renear, David Dubin, and Claus Huitfeldt discussed inferences that can be drawn from markup, returning to a theme that started with Sperberg-McQueen's keynote from two years ago. Wendell Piez, who last year took a rhetorical approach to markup, this year approached it from the perspective of semiotics and structural linguistics. Jeni Tennison showed an algebraic approach to comparing markup languages. Simon St. Laurent examined the possibilities of using stand-off markup (rather than the more conventional embedded tags), an approach favored by hypertext pioneer Ted Nelson. Stand-off markup requires pointers such as can be derived from Nichol's range 
algebra. Tennison and Piez delivered another paper that showed how to use pointer-based approaches to do layered annotation and multiple hierarchies in a single document. Patrick Durusau presented a different approach to hierarchies, with techniques for selecting among concurrent or overlapping trees in conventional tag-based markup.

Jack Park's keynote on the Open Hyperdocument system proposed by Douglas Engelbart examined the implications of having a massively hyperlinked online system for collaboration. The idea of a hyperlinked system for managing information is usually traced back to Vannevar Bush's 1945 article, "As We May Think" (http://www.theatlantic.com/unbound/flashbks/computer/bushf.htm), but Bush's vision could not be implemented with the technology of the day. His intellectual successor, Engelbart, created the ancestor of all modern hypertext systems, NLS (for "oN-Line System"), in the late 1960s; one of the many secondary contributions of this system was the invention of the computer mouse. The continuing theme of Englebart's research, and of Park's keynote, is the "augmentation of human intellect" through technology. Among the projects that Park discussed are some to put tools for interaction and collaboration in the hands of schoolchildren (e.g., the "Nexist" project, http://nexist.sourceforge.net/, and his paper from an earlier IDEAlliance conference, "Bringing Knowledge Technologies to the Classroom," http://www.thinkalong.com/JP/ParkKT2001.pdf). Eugene Kim, from Englebart's Bootstrap Institute, and Ken Holman presented a paper on the data structures and interchange formats being used in the Open Hyperdocument system.

Bush's original article proposed that his hypothetical tool for knowledge management, the "Memex," go beyond mere indexing. To Bush, what distinguishes the human mind is its ability to form associations, and the Memex was to be, among other things, a tool for collecting webs of associations. Today, among the most promising tools for collecting associations are systems based on Topic Maps. As at most recent conferences, there were several papers on Topic Maps, ranging from Eric Freese's question "So why aren't Topic Maps ruling the world?" to Mary Nishikawa's presentation of how a large corporation uses Topic Maps in an intranet. Vinh Lê, from the DOE office of Information Classification and Control Policy, and I presented a paper on "Topic Maps for Managing Classification Guidance."

The other papers at the conference were spread over a wide range of subjects, including automatic indexing, instructional workstations, synchronized multimedia, and development tools. There were several papers on querying and database techniques. Because there were parallel tracks, I was unable to attend all the sessions.

As in past years, the conference was quite lively, and there is not only a continuation of rapid growth in interest in the SGML/XML world but also, and probably more importantly, a wide range of intellectual inquiry into techniques and new areas of application. Other XML conferences have increasingly become dominated by electronic-business concerns. Extreme Markup Languages, however, remains centered on the original concerns of those of us who developed structured markup more than twenty years ago, enhancing the effectiveness of communications among humans.

\section{Conclusion and Recommendations}

The world of markup languages appears to be quite healthy, whether one looks at the fundamental level of standards development or the upper layers of application.

Although DOE has been involved with SGML and structured markup since the late 1970s, interest in these subjects has tended to reside in specialized groups. The rise of the WWW brought a casual, if frequently effective, use of SGML (in the form of HTML) to a wide community but did not spread wide understanding of the underlying technology. The rise of XML and its adoption by major software houses 
suggests that use will become even more widespread. For some uses, a casual approach to XML may suffice. However, for records, product data, interpretive knowledge bases, and other mission-sensitive information, DOE should take an active position on the development and use of SGML-related standards.

The growth of Topic Maps and other XML-based mechanisms for knowledge engineering has potentially great impacts on mission-critical information for DOE and NNSA. As NNSA's weapons programs increasingly call for electronic data capture, there is a need for stable mechanisms for both capturing and cataloging the information. Particularly in the case of stockpile life-extension programs, there is a need for this data to be usable for decades after it is collected. Current methods of collecting the data do not offer adequate assurance that that the data will continue to be usable. Adoption and implementation of standard methods based in SGML/XML should be a high priority for DOE and NNSA.

The application of XML and Topic Maps to knowledge management in projects such as that for the Ferret classification engine should be pursued. The application of Topic Maps to classification guidance at the office of Information Classification and Control Policy, on which we reported at this conference, should lead to better distribution of classification information within DOE and NNSA. The work of SC34/WG3 at this meeting has resulted in some rethinking of the design of the Topic Map being planned for managing classification guidance. Participation in the meeting was highly beneficial. DOE should look for ways of extending the Topic Map technique beyond its current applications.

Because DOE is one of the organizations adopting SC34 standards, it should continue active participation in SC34's work, particularly the work on Topic Maps. As DOE's use of these standards increases, the need for continued commitment to their maintenance and extension will increase as a consequence. DOE should also keep aware of developments in the realm of applications by participating in conferences and developers' groups. Furthermore, DOE should establish more internal means for sharing tools, techniques, and applications. Extension of the NWIG metadata system and construction of a comprehensive records system such as that proposed by Y-12's WRAP project can profit from DOE's future support of SGML/XML. Ferret technology seems a good candidate for extension to other DOE facilities and perhaps for commercialization as well. Y-12, as the leader in development of SGML-related standards, is in a good position to continue also as a leader in their application.

\section{Future meetings}

SC34 has the following meetings scheduled for the next year:

\begin{tabular}{lll}
\hline \multicolumn{1}{c}{ Group } & \multicolumn{1}{c}{ Dates } & \multicolumn{1}{c}{ Location } \\
\hline SC34 & 7-12 December 2002 & Baltimore \\
SC34 & May 2003 & Amsterdam or Brussels \\
SC34 & December 2003 & Philadelphia \\
\hline
\end{tabular}

Project meetings may also be scheduled between SC34 meetings.

SC34 continues to schedule most of its meetings in conjunction with conferences sponsored by IDEAlliance. These conferences generally deal with SGML, XML, HyTime, DSSSL, and related topics; combining meetings with the IDEAlliance conferences allows a reduction in the number of trips for experts who participate in both activities. 


\section{Appendix A}

\section{James David Mason: Itinerary, 2-10 August 2001}

\begin{tabular}{llll}
\hline \multicolumn{1}{c}{ Dates } & \multicolumn{1}{c}{ Location } & \multicolumn{1}{c}{ Contacts } & \multicolumn{1}{c}{ Purpose } \\
\hline 2 August 2002 & $\begin{array}{l}\text { Knoxville; Montréal, } \\
\text { Quebec, Canada }\end{array}$ & & Travel \\
& Montréal & $\begin{array}{l}\text { Jane Harnad } \\
\text { (IDEAlliance, hosts) }\end{array}$ & $\begin{array}{l}\text { Meeting of ISO/IEC } \\
\text { JTC1/SC34/WG3 } \\
\text { Conference: } \text { Extreme } \\
\text { 3-5 August 2002 }\end{array}$ \\
6-9 August 2002 & Montréal & $\begin{array}{l}\text { Jane Harnad } \\
\text { (IDEAlliance, hosts) }\end{array}$ & $\begin{array}{l}\text { Markup Languages 2002 } \\
\text { Return travel }\end{array}$ \\
\hline
\end{tabular}




\section{Appendix B}

\section{Principal Contacts}

\section{ISO/IEC JTC1/SC34WG3, Montréal Meeting Attendance \\ and \\ Contacts at Extreme Markup Languages 2002 \\ August 2002}

Mr. Syd Bauman
Scholarly Technology Group
Brown University Box 1841
Providence, RI 02912-1841
E-mail: Syd_Bauman@brown.edu
Telephone: $401863-3835$

Mr. Lawrence A. Beck

Reed Technology

275 Gibralter Road

Hosrsham, PA 19044

Telephone: +1 3019634410

E-mail: lbeck@rtis-g.com

Dr. Michel Biezunski

Coolheads Consulting

402 85th Street, No. 5

Brooklyn, NY 11209

Telephone: +1 7189210901

E-mail: mb@infoloom.com

Dr. Steven J. DeRose

1908 Wallace Ave.

Silver Springs, Maryland 20902

Telephone: +1 301-949-6544

E-mail: sderose@speakeasy.net

\begin{tabular}{lcc} 
& S & E \\
\hline $\begin{array}{l}\text { Dr. Patrick Durusau } \\
\text { Society for Biblical Literature }\end{array}$ & x & x \\
The Luce Center, Suite 350 & & \\
825 Houston Mill Road & & \\
Atlanta, GA 30329 & \\
Telephone: +1040 727 3100 & \\
E-mail: pdurusau@emory.edu &
\end{tabular}

$\mathrm{x}$

\author{
Mr. Peter Flynn \\ Silmaril \\ 6 Halldene Lawn \\ Bishopstown \\ Cork, Ireland \\ E-mail: peter@silmaril.ie
}

$\mathrm{X} \quad \mathrm{X}$

Mr. Eric Freese
LexisNexis Matthew Bender
1722 Elm St.
White Bear Lake, MN 55110
Telephone: +1 6127480293
E-mail.com: eric.freese@lexisnexis.com


S E

Mr. Joseph V. Gangemi

$\mathrm{X}$

JVG Consulting Services

20 Carriage Stop Drive

Berlin, N.J. 08009-1196

Telephone: $=18568090517$

E-mail: jvgangemi@comcast.com

Mr. Lars Marius Garshol

X $\mathrm{X}$

Ontopia AS

Waldemar Thranes gate 98

N-0175 Oslo, Norway

Telephone: +4723233080

E-mail: larsga@ontopia.net

Ms. Jane Harnad

IDEAlliance

100 Daingerfield Rd., Fourth Flr.

Alexandria, VA 22314

Telephone: +1.703.837.1095

E-mail: jharnad@idealliance.org

Mr. Sam Hunting

$\mathrm{X} \quad \mathrm{X}$

eTopicality

912 Pine Street \#4

Philadelphia, PA 19107

Telephone:+1 661-547-6510

E-mail: sam_hunting@yahoo.com

Mr. Eliot Kimber, ISOGEN International, $\mathrm{x} \quad \mathrm{x}$ 2608 Pinewood Terrace, Austin, TX 78757

Ms. Deborah A. Lapeyre

$\mathrm{X}$

Mulberry Technologies, Inc

17 West Jefferson Street, Suite 207

Rockville, MD 20850

Telephone: +1 3013159633

E-mail: dlapeyre@mulberrytech.com

Mr. Vinh Lê

$\mathrm{X}$

\section{S E}

Dr. Pierre Lévy

$\mathrm{X}$

Department of Communication

University of Ottawa

556 King Edward

Ottawa, Ontario, Canada

Telephone: +1 613-562-5800 Ext. 3840

E-mail: plevy@uottawa.ca

Dr. James David Mason

Y-12 National Security Complex

Bldg. 9113, Room 337I

P.O. Box 2009, M.S. 8208

Oak Ridge, TN 37831-8298

Telephone: +1 8655746973

E-mail: mxm@y12.doe.gov

Mr. Graham Moore

$\mathrm{X} \quad \mathrm{X}$

empolis UK Ltd.

Unit B

The Dorcan Complex

Faraday Road

Swindon SN35HQ United Kingdom

Telehone: +44 1793485465

E-Mail: gdm@empolis.co.uk, http://www.empolis.co.uk,

Dr. Steven R. Newcomb

$\mathrm{X} \quad \mathrm{X}$

Coolheads Consulting

1527 Northaven Drive

Allen, Texas 75002

Telephone: +19723598160

E-mail: srn@coolheads.com

Ms. Mary Nishkawa

$\mathrm{X} \quad \mathrm{X}$

Schlumberger K. K.

2-2-1 Fuchinobe

Sagamihara, Kanagawa 229-0006

Telephone: +81-42-759-5376

Facsimile: +81-42-759-3563

E-mail: mnishikawa@slb.com

U. S. Department of Energy, SO-122

19901 Germantown Road

Germantown, MD 20874-1290

E-mail: 


\begin{tabular}{lcc} 
& S & E \\
\hline Dr. Nikita Ogievetsky & x & x \\
Cogitech, Inc. & &
\end{tabular}

Cogitech, Inc.

P.O. Box 72

Hewlett, NY 11557-0072

Telephone: +19174068734

E-mail: nogievet@cogx.com

Dr. Wendell A. Piez

$\mathrm{X}$

Mulberry Technologies, Inc

17 West Jefferson Street, Suite 207

Rockville, MD 20850

Telephone: +1 3013159635

E-mail: wapiez@mulberrytech.com

Dr. Lynne Price

$\mathrm{X}$

Text Structure Consulting, Inc. 17225 San Franciscan Drive Castro Valley, CA 94552 U.S.A.

Telephone: +1 510 583-1505

Facsimile: +1 510 583-1505

E-mail: 1price@txstruct.com

Dr. Hans Holger Rath

empolis $\mathrm{GmbH}$

Havelstr. 9

64295 Darmstadt

Germany

Telephone: +49.172 .66 .90 .427$

Facsimile: +499365 806266

E-mail: holger.rath@empolis.com

Dr. Allen Renear

Graduate School of Library and

Information Science

University of Illinois at Urbana-

Champaign

501 East Daniel St.

Champaign, IL 61820

Telephone: +1 217 265-5216

e-mail: renear@uiuc.edu
Dr. C. Michael. Sperberg-McQueen

Wold Wide Web Consortium

259 State Road 399

Española, New Mexico 87532-3170

E-mail: cmsmcq@w3.org

Telephone: +1 5057474224

Ms. B. Tommie Usdin

Mulberry Technologies, Inc

17 West Jefferson Street, Suite 207

Rockville, MD 20850

Phone: +1 301 315-9631

E-mail: btusdin@mulberrytech.com

M. Bernard Vatant

X X

Mondeca

Les Aubergeries

05380 Châteauroux-les-Alpes

France

Telephone: 33492432071

E-mail: bernard.vatant@mondeca.com

Ms. Ann Wrightson

X $\mathrm{X}$
15 Kensington Close

Batley, West Yorkshire WF17 7RL

United Kingdom

Telephone: +441491630050

E-mail: ann.wrightson@alphaxml.com 


\section{Appendix C}

\section{Literature Acquired}

ISO/IEC JTC1/SC34WG3 distributed no new documents in the course of the Montréal meeting. The report of the WG3 meeting, SC34 N331, is at http://www.y12.doe.gov/sgml/sc34/document/0331.htm

The Proceedings of the GCA Conference Extreme Markup Languaes 2002 are available from Dr. Mason. 


\section{DISTRIBUTION}

\section{DOE DISTRIBUTION}

1. Ms. C. S. Blackston, U. S. Department of Energy, 19901 Germantown Road, HR-34, Room C137, Germantown, MD 20874-1290

2. Mr. William J. Brumley, DOE-ORO Y-12 Site Office

3. Mr. Philip A. Carpenter, DOE-ORO ORNL Site Office

4. Ms. Debbie Cutler, OSTI, P.O. Box 62, Oak Ridge, TN 37831

5. Ms. Kelli Holden, Bldg. K-1030, MS-7312

6. Mr. Vinh Lê, U. S. Department of Energy, SO-122, 19901 Germantown Road, Germantown, MD 20874-1290

7. Mr. R. C. Morgan, Manager, Office of Scientific and Technical Information,OSTI

8. Mr. Axel Ringe, Office of Scientific and Technical Information, OSTI

9. Mr. Donat R. St. Pierre, Safeguards and Security, ORO

10. Mr Lawrence Sanchez, U. S Department of Energy, IN-1, Room GA-301, Forrestal Building, Washington, DC 20585

11. Dr. Andrew P Weston-Dawkes, U. S. Department of Energy, SO-122, 19901 Germantown Road, Room J-309, Germantown, MD 20874-1290

12. Mr. B. R. White, U. S. Department of Energy, 19901 Germantown Road, HR-34, Room C-137, Germantown, MD 20874-1290

13. Threat Reduction Team, 4x24 NHB, Washington, DC 20505

14-15. Office of Scientific and Technical Information, OSTI

\section{INTERNAL DISTRIBUTION}

$\begin{array}{ll}\text { 16. } & \text { R. Baylor } \\ \text { 17. } & \text { R. A. Beard } \\ \text { 18. } & \text { M. A. Bell } \\ \text { 19. } & \text { M. J. Borgsmillser } \\ \text { 20. } & \text { D. K. Briscoe } \\ 21 . & \text { L. J. DeMarotta } \\ 22 . & \text { K. M. Dobbs } \\ 23 . & \text { M. D. Galyon } \\ 24 . & \text { D. S. Griffith } \\ 25 . & \text { T. M. Insalaco } \\ 26 . & \text { J. C. Johns } \\ 27 . & \text { S. R. Jordan } \\ 28 . & \text { A. J. Klein }\end{array}$

16. R. Baylor

17. R. A. Beard

18. M. A. Bell

19. M. J. Borgsmillser

D. K. Briscoe

21.
otta

A. J.
29. P. J. Kortman

30. C. H. Malarkey

31. J. D. Mason

32. S. H. McConathy

33. P. M. McCoy

34. R. W. McGaffey

35. K. M. McKeehan

36. B. K. Robinette

37. J. R. Snyder

38. T. O. Tallant

39. E. W. Whitfield

40. Y-12 Plant Records Department

41. Foreign Travel Office-RC 


\section{EXTERNAL DISTRIBUTION}

41. Dr. David Abrahamson, Trinity College, Computer Science Department, O'Reilley Institute, Dublin, 2 Ireland

42. Ms. Barbara Beeton, American Mathematical Society, 201 Charles Street, P.O. Box 6248, Providence, RI 02940

43. Dr. Doris Bernardini, DoD/DISA/Center for Standards, Code JEBE, 10701 Parkridge Road, Reston, VA 22091-4398, U.S.A.

44. Dr. Michel Biezunski, Coolheads Consulting, 1527 Northaven Drive, Allen, TX, 75002-1648

45. Mr. Martin Bryan, The SGML Centre 29, Oldbury Orchard Churchdown, Gloucester GL3 2PU United Kingdom

46. Mr. Robin Cover, ISOGEN International, 6634 Sarah Drive, Dallas, TX USA 75236

47. Dr. Patrick Durusau, Society for Biblical Literature, Atlanta, GA

48. Mr. Marion Elledge, IDEAlliance, 100 Daingerfield Rd., Alexandria, VA 22314-2888

49. Mr. Paul A. Ellison, Computer Unit, University of Exeter, Laver Building, North Park Road, Exeter EX4 4QE, United Kingdom

50. Dr. Martin J. Fritts, 1710 SAIC Drive, P.O. Box 1303, Mail Stop 2-6-9, McLean, VA 22102

51. Ms. Pam Gennusa, 175 East Delaware Place, Apt 9010, Chicago, IL 60611

52. Dr. Charles F. Goldfarb, Information Management Consulting, 13075 Paramount Drive, Saratoga, CA 95070

53. Ms. Sara Hafele, (ISO/IEC JTC1/SC34 Secretariat), American National Standards Institute, 25 West 43rd Street, New York, NY 10036

54. Sam Hunting, eTopicality, 912 Pine Street \#4, Philadelphia, PA 19107

55. Mr. G. Ken Holman, Crane Softwrights Ltd., 1605 Mardick Court, Box 266, Kars, Ontario K0A-2E0, Canada

56. Mr. Scott Jameson, Chairman ISO/IEC JTC1, Hewlett-Packard Company, P.O. Box 130605, The Woodlands TX 77393

57. Mr. Eliot Kimber, ISOGEN International, 2608 Pinewood Terrace, Austin, TX 78757

58. Dr. Yushi Komachi, Panasonic/MCGS, 2-3-8 Shimomeguro, Meguro-ku, Tokyo 153, Japan

59. Mr. Kenneth J. Lasky, SAIC, 4001 North Fairfax Drive, Suite 300, Arlington, VA 22203

60. Mr. Bruce E. Lownsbery, Lawrence Livermore National Laboratory, Mailcode L-170, 7000 East Ave., P.O. Box 808, Livermore, CA 94550

61. Dr. Tamara J. Miller, 611 Hodges Library, University of Tennessee, Knoxville, TN 37996

62. Mr. Graham Moore, empolis UK Ltd., Unit B, The Dorcan Complex, Faraday Road, Swindon SN3 5HQ, United Kingdom

63. Dr. Steven R. Newcomb, Coolheads Consulting, 1527 Northaven Drive, Allen, TX, 75002-1648

64. Mr. Eamonn Neylon, Manifest Solutions, John Eccles House, Robert Robinson Avenue, Oxford Science Park, Oxford OX4 4GP, United Kingdom

65. Dr. Nikita Ogievetsky, Cogitech, Inc., P.O. Box 72, Hewlett, NY 11557-0072

66. Mr. Steve Pepper, Ontopia A.S., Waldemar Thranes gate 98, N-0175 Oslo, Norway

67. Dr. Lynne Price, 48680 Taos Road, Fremont, CA 94539

68. Mr. Roger Price, Department of Computer Science, University of Massachusetts Lowell, One University Avenue, Lowell, MA 01854

69. Mr. Daniel Rivers-Moore, RivCom, Lotmead Business Village, Swindon, Wiltshire SN4 OUY, United Kingdom

70. Dr. Hans Holger Rath, empolis GmbH Havelstr. 964295 Darmstadt, Germany 
71. Mr. Rudolph M. Riess, 15 Hersam, Stoneham MA 02180

72. Mr. Norman Scharpf, IDEAlliance, 100 Daingerfield Rd., Alexandria, VA 22314

73. Mr. Jerry L. Smith, Code JEBCD, DISA Center for Standards, 10701 Parkridge Boulevard, Reston, VA 20191-4357

74. Mr. David Steinhardt, IDEAlliance,100 Daingerfield Rd., Alexandria, VA 22314-2888

75. Dr. Richard Strehlow, 5120 Kingston Pike, Knoxville, TN 37919

76. Ms. B. Tommie Usdin, Mulberry Technologies, Inc, 17 West Jefferson Street, Suite 207, Rockville, MD 20850

77. M. Bernard Vatant, Mondeca, Les Aubergeries, 05380 Châteauroux-les-Alpes, France

78. Ms. Yvonne Vine, The International SGML/XML Users' Group, P.O. Box 361, Swindon, Wiltshire SN25 4ZT, United Kingdom

79. Ms. Ann Wrightson, alphaXML Limited, 15 Kensington Close, Batley, West Yorkshire WF17 7RL, United Kingdom 